\title{
Sen and Žižek on the Culturalization of Violence
}

Marlon Jesspher B. De Vera

\begin{abstract}
This paper presents areas of convergence in the thoughts of Amartya Sen and Slavoj Žižek on how violence is culturalized and consequently mystified. First, Žižek's ideas on the culturalization of politics are explicated. Second, Sen's notions on the mystification of identity and his conception of rationality are discussed. Third, Sen's and Žižek's common criticisms of the clash of civilization theory in relation to religious violence are elaborated. Lastly, from synthesizing Sen's and Žižek's thoughts, key theses are provided on how the culturalization of politics and identity mystifies violence by rendering its axiomatic, universal, and rational political dimension as cultural, particularist, and non-ideological.
\end{abstract}

Keywords: Sen, Žižek, violence, culturalization

A martya Sen and Slavoj Žižek believe that one prominent way in which violence is mystified is when it is culturalized. This 1 mystification pertains to the fundamental character of the problem of violence and is one among multiple ways by which violence is mystified. In the present discussion, culturalization means the tendency towards formulating the problem of violence primarily as a cultural problem, while underplaying or excluding from the formulation the other central dimensions of violence. Both Sen and Žižek criticize contemporary cultural theories for their culturalized views on the problem of violence. Both likewise assert the central political, social, and economic dimensions of violence, which need to be recognized and analyzed to truly demystify violence. Demystifying violence is meaningful in the sense that it motivates towards gaining a more nuanced and more clarified conception and understanding of violence, its fundamental character, its mechanisms and causes, and its potential solutions. 


\section{SEN AND ŽIŽEK}

\section{The Culturalization of Politics}

Slavoj Žižek situates what he calls the culturalization of politics ${ }^{1}$ within the broader criticism of what he calls the pseudo-political milieu of contemporary liberal capitalist society. He characterizes this pseudo-political milieu as post-political bio-politics. It is post-political because it is devoid of grand political motivations, and consequently it is bio-political because it is merely concerned with humanity as bare life. This results into an atonal world without a Master Signifier, ${ }^{2}$ with the strongest ideology taking the form of its opposite, that of the neutralization of ideology. Post-political bio-politics is pseudo-political also in the sense that it eliminates the essential axiomatic character of politics which consists of the advancement of common grand political ideals for a society. This is replaced with a non-axiomatic, particularist framework, which consists of a minimal regard for humanity as bare life, with everything else beyond that being grounded on particular ways of life. In this way, post-political bio-politics leads to the culturalization of politics, in the sense that the political characters of problems such as violence are undermined. Instead, these problems are reduced and formulated as primarily cultural problems, or problems that are brought about by conflicts amongst different ways of life. In other words, for Žižek, culturalization is the process of rendering politics vacuous of any meaning, and consequently subjugating the political character of social problems to a primarily culturalist view. In such a pseudo-political mode, the only mobilizing force is fear (against other different particular ways of life), which is manifested in the contemporary world's obsession with liberal tolerance and political correctness which, paradoxically, occurs simultaneously with the increasing prevalence of anti-immigration sentiments. Thus, in a sense, tolerance for the other also means intolerance against the overproximity of the other. Another contemporary example that Žižek cites is the phenomenon of liberal communists, wherein the same billionaire philanthropists that donate massive amounts to social causes are the same capitalists that systematically drive disproportionate socioeconomic and political inequality and injustice. ${ }^{3}$

In "A Leftist Plea for Eurocentrism," Žižek proposes the re-assertion of democratic politics as a genuine European legacy to resist the culturalization or depoliticization of politics. Žižek espouses a definition of politics proper as precisely democracy, which he claims has its roots in ancient Greece when the demos (those who did not have a clearly determined position in the social hierarchy) put themselves forward as the

\footnotetext{
${ }^{1}$ Slavoj Žižek, Violence: Six Sideways Reflections (New York: Picador, 2008), 140.

2 Žižek borrows this characterization from Alain Badiou.

${ }^{3}$ Žižek, Violence, 34-41.
} 


\section{DE VERA 3}

representatives of society as a whole, or in other words, as the real universality against the hegemonic interest of the ruling class. This consequently led to the initiation of the democratic logic of separating the master (a mere contingent person) from the position or place of power because if the positionless status of the demos can become contingent through their assertion as the rightful representatives of society, then the positioned status of the masters can also be consequently rendered contingent. Thus, in a paradoxical movement typical of Žižek, he clarifies that the Eurocentrism he espouses is not the sort that aims to privilege the European agenda, but rather the sort of Eurocentrism founded on the European legacy of democracy which elevates the true non-particular, universal political interest. For Žižek, this sort of Eurocentrism has the potential for the political left to revive its relevance amidst the contemporary phenomena of depoliticization or disavowal of politics. ${ }^{4}$ In a sense, Žižek admonishes that a dangerous trap which the political left need to be cautious of is the trap of engaging in contemporary social, economic, and political issues in a way that is already framed within the coordinates of post-political bio-politics. These coordinates are characterized by the tolerant and politically-correct formulation of these problems as primarily functions of differences in culture or particular ways of life. Thus, in a symbolically intolerant and politically-incorrect way, Žižek urges the political left to advance the "Eurocentric" ideals of democratic politics to resist the phenomenon of culturalization in the contemporary milieu of post-political bio-politics.

As a supplement, Žižek identifies two distinct phenomena characterizing the failures in post-communist Eastern Europe to re-assert the true European legacy of democracy. ${ }^{5}$ First is the lingering power of totalitarian forces and second is the accelerated rise of radical nationalism. For Žižek, these phenomena are not mere symptoms of a lacking or incomplete project but constitutive transgressions necessary to reconstruct the European identity while the underlying antagonisms that perpetuate the deadlock against the reassertion of the true European legacy of democracy are not addressed. ${ }^{6}$ In other words, these two phenomena are not brought about by the extreme assertion of the strong political ideals of totalitarianism and nationalism. On the contrary, these phenomena came about through the culturalized, post-political bio-political milieu of post-communist Eastern Europe. Thus, overcoming both the lingering totalitarian forces and the rise of radical nationalism would entail surpassing the culturalized, tolerant, and politically-correct formulation of these problems, and asserting the true

4 Slavoj Žižek, "A Leftist Plea for 'Eurocentrism'," in Critical Inquiry, 24 (Summer 1998).

${ }^{5}$ Slavoj Žižek, "Eastern European Liberalism and Its Discontents," in New German Critique, 57 (Autumn 1992).

${ }^{6} \mathrm{Ibid}$.

(C) 2021 Marlon Jesspher B. De Vera https://www.kritike.org/journal/issue 29/devera december2021.pdf ISSN 1908-7330 


\section{SEN AND ŽlŽEK}

European legacy of democratic politics. This seemingly paradoxical thesis that it is precisely culturalization and post-political bio-politics (and their overt manifestations as liberal tolerance and political correctness) that lead to radical politics is consistent with Žižek's more recent analyses of the rise of new radical populist, alt-right, or nationalist politics across the world, including in the Philippines.

Žižek situates this deadlock against the re-assertion of the true European legacy of democratic politics in Eastern Europe within the distinction between universalization and globalization. ${ }^{7}$ Genuine universalization is the requisite movement towards the realization of the politicization through democracy when the whole synchronizes with the previously excluded part. On the other hand, globalization is the movement consistent with post-political ideology and is thus a potent threat against the real re-assertion of the true European legacy of democracy. In other words, universalization is characterized by genuine democratic social integration, equality, and justice. While it might seem counter-intuitive, Žižek asserts that the contemporary phenomenon of globalization is inconsistent with the democratic ideal of universalization. This is because while the contemporary phenomenon of globalization integrates global capital, it thrives in the further particularization and depoliticization of societies and peoples. As Žižek posits, this is because the tolerant and politically-correct culturalization of societies and peoples as merely different particular ways of life is structurally favorable for the propagation of global capital. Culturalization promotes the propagation of global capital in the way that it mystifies the broader social, economic, and political roots of injustice and inequality, under the guise of respect and tolerance for different cultures and ways of life. It is in the culturalized movement of globalization that various modalities of depoliticization or pseudo-politicization emerges-from communitarian archae-politics which situates the political within the aim to go back to collective communitarian roots, to postmodern deconstructionist parapolitics which is consistent with the apolitical characteristic of post-political bio-politics, to ultra-politics founded on military power, which Jacques Rancière identifies as the "police" aspect of sustaining social order, as opposed to politics proper which is characterized by democracy. ${ }^{8}$

For Žižek, the contemporary multiculturalist notion of tolerance is a central manifestation of the culturalization of politics, wherein problems such as violence, which are essentially rooted in political and economic conflicts, are reduced to functions of cultural differences.

\footnotetext{
${ }^{7}$ Slavoj Žižek, "For a Leftist Appropriation of the European Legacy," in Journal of Political Ideologies, 3 (February 1998).

${ }^{8}$ Ibid.
}

(C) 2021 Marlon Jesspher B. De Vera

https://www.kritike.org/journal/issue 29/devera december2021.pdf

ISSN 1908-7330

(c) ) BY-NC-ND 


\section{DE VERA 5}

Political differences-difference conditioned by political inequality or economic exploitation-are naturalized and neutralized into "cultural" differences, that is, into different "ways of life" which are something given, something that cannot be overcome. They can only be "tolerated."

Because of the depoliticized character of the discourse of tolerance, it is susceptible to what Kant calls the antinomies of reason, wherein each of two diametrically opposed positions can formulate its own versions of arguments founded on a notion of tolerance, and both sets of arguments would seem valid. ${ }^{10}$ This can be illustrated again by the previously described examples on the phenomenon of liberal communists and the discourse of liberal tolerance that also means intolerance against the overproximity of the other. This results in a deadlock of guilt and fear which further reinforces the depoliticized character of the discourse.

Ultimately, Žižek's analysis asserts that the process of culturalization is necessary for the seamless functioning of the global mechanistic logic of capitalism, which is also in itself "wordless" or meaningless, a truth-withoutmeaning. ${ }^{11}$ It is through this political worldlessness or emptiness that the logic of capitalism asserts itself as truly global or universal, as seamlessly functional across the multitude of particularist cultural contexts.

From an intellectual standpoint, Žižek also traces the roots of the phenomenon of culturalization from a distinct phenomenon of the emergence of the new typologies of public intellectuals. ${ }^{12}$ Žižek observes that concurrent with the decline of the modern public intellectual who is also a political theorist that advances genuine engagement in public debates on relevant social and political issues, is the emergence of two types of new public intellectuals, namely the postmodern-deconstructionist cultural studies scholar and the scientific cognitivist, also referred to as the proponent of the so-called Third Culture. While Žižek attributes the intellectual roots of depoliticization to the rise of postmodern-deconstructionist cultural studies, he likewise draws attention to the equally potent mystifications brought about by the emergence of the Third Culture or scientific cognitivism. The Third Culture movement has disproportionately presented scientists as unprecedented and unequalled experts on a broad range of areas of inquiry, often extending beyond the conventional boundaries of analytical and

\footnotetext{
${ }^{9}$ Žižek, Violence, 140.

${ }^{10}$ Ibid., 105.

${ }^{11}$ Ibid., 79.

12 Slavoj Žižek, "Cultural Studies versus the "Third Culture'," in The South Atlantic Quarterly, 101 (Winter 2002).
}

(c) 2021 Marlon Jesspher B. De Vera https://www.kritike.org/journal/issue 29/devera december2021.pdf ISSN 1908-7330 


\section{SEN AND ŽIŽEK}

empirical science. Two specific mystifications are brought about as a consequence of the Third Culture phenomenon. First is the mystification of scientific obscurantism, wherein scientific conceptions such as quantum theory are increasingly appropriated into philosophical and cultural contexts in a greatly obscure and mystifying manner. Scientific obscurantists have leveraged on this trend by reconfiguring and obscuring scientific ideas to present new mystical wisdom. Second is the mystification of the "naturalization of culture" advanced by cultural studies public intellectuals in close conjunctive reference to the principles of the Third Culture movement. When culture is rendered as natural, it is presented as a direct manifestation of the true metaphysical states of affairs and thus advanced as the primary driving force of human social reality. A consequence of the mystification of the "naturalization of culture," is its opposite mystification "the culturalization of nature." As such, the cultural becomes identical with the natural and consequently, what is natural is conflated into the cultural, and what is cultural is naturalized. Some examples that Žižek cites include cyberevolutionism which is the conception of the internet as a natural organism that is self-evolving, cybernetic notions of life or the Earth founded on information transmission and coding/decoding, and ideas of society and markets as living organisms. ${ }^{13}$ These intellectual mystifications contribute towards the overall mystification of the culturalization of politics wherein politics is subordinated to culture and moreover, such subjugation is naturalized.

Žižek discusses one more form of the mystification of culturalization. ${ }^{14}$ The form of mystification in question is radical historicism, which aims to reduce political notions into the concrete material and historical conditions of their emergence. This is a problem for Žižek as radical historicism undermines and renders impossible any claim to universality of political conceptions and ideals. Thus, radical historicism is one of the main modalities of cultural studies and culturalization. In response, Žižek attempts to draw a distinction between radical historicism and true postmodern deconstruction, particularly that of Jacques Derrida. Žižek asserts that if conducted in its true spirit, postmodern deconstruction can construct an undistorted portrayal of history and serve as a resisting force against radical historicism. This is through a conduct of postmodern deconstruction that genuinely deconstructs historical mystifications and renders the distortions involved in these mystifications palpable. Žižek further asserts that the distorted brand of postmodern deconstruction being perpetuated by cultural

\footnotetext{
${ }^{13}$ Ibid.

${ }_{14}$ Slavoj Žižek, "History against Historicism," in European Journal of English Studies, 4
} (2000).

(C) 2021 Marlon Jesspher B. De Vera

https://www.kritike.org/journal/issue 29/devera december2021.pdf

ISSN 1908-7330

(c) $)$ BY-NC-ND 


\section{DE VERA 7}

studies is merely a misperception of certain American appropriators of Derrida. ${ }^{15}$

The different and overlapping nuances of the multiple forms of culturalization that Žižek identifies and that were discussed in this section are summarized in table below.

\begin{tabular}{|c|c|c|c|}
\hline $\begin{array}{l}\text { Culturalized } \\
\text { Dimension }\end{array}$ & Primary Form & $\begin{array}{l}\text { Manifestations } \\
\text { and/or Examples }\end{array}$ & Counterpoint \\
\hline Politics & $\begin{array}{l}\text { Post-political bio- } \\
\text { politics }\end{array}$ & $\begin{array}{l}\text { Liberal tolerance, } \\
\text { political } \\
\text { correctness, } \\
\text { lingering } \\
\text { totalitarian forces, } \\
\text { rise of radical } \\
\text { nationalism }\end{array}$ & Democracy \\
\hline $\begin{array}{l}\text { Political } \\
\text { economy }\end{array}$ & Globalization & $\begin{array}{l}\text { Communitarian } \\
\text { archae-politics, } \\
\text { postmodern } \\
\text { deconstructionist } \\
\text { para-politics, } \\
\text { ultra-politics }\end{array}$ & Universalization \\
\hline $\begin{array}{l}\text { Intellectual } \\
\text { life }\end{array}$ & $\begin{array}{l}\text { Third Culture } \\
\text { (postmodern- } \\
\text { deconstructionist } \\
\text { cultural studies, } \\
\text { scientific } \\
\text { cognitivism) } \\
\end{array}$ & $\begin{array}{l}\text { Scientific } \\
\text { obscurantism, } \\
\text { naturalization of } \\
\text { culture, } \\
\text { culturalization of } \\
\text { nature }\end{array}$ & Political theory \\
\hline History & $\begin{array}{l}\text { Radical } \\
\text { historicism }\end{array}$ & $\begin{array}{l}\text { Political notions } \\
\text { reduced the } \\
\text { concrete material } \\
\text { and historical } \\
\text { conditions of their } \\
\text { emergence }\end{array}$ & Deconstruction \\
\hline
\end{tabular}

\section{Mystifications of Identity}

Sen, on the other hand traces the roots of the mystification of culturalization to the more fundamental conceptual mystifications of the idea

${ }^{15}$ Ibid.

(C) 2021 Marlon Jesspher B. De Vera https://www.kritike.org/journal/issue 29/devera december2021.pdf 


\section{SEN AND ŽIŽEK}

of identity. ${ }^{16}$ Early on in his text, Sen acknowledges the dual force of identity. On one hand, it can be a source of confidence and strength (or "social capital," Sen borrowing from Robert Putnam) within members of the same group. On the other hand, it can also be used to promote hatred against people of a different group. ${ }^{17}$ Thus, when identities are mystified or culturalized to the extent that fosters hatred against people of a different group, these mystified identities can be instrumentalized to instigate violence. Conversely, when identities are demystified and appropriately understood holistically across not only their cultural, but also their social, economic, and political contexts, identities can be employed as sources of solidarity within a group and amongst different groups. In similar fashion, Žižek acknowledges the question of how the same people who are violent against opponents could be gentle and warm towards people whom they identify with within the same group. His proposed initial response to this question is consistent with his analysis of the culturalization of politics-it is precisely in an atonal, particularist, non-ideological worldview that fetishistic disavowal (of the form "I know very well but ...") becomes constitutive of ethical stances. ${ }^{18}$ In other words, it is precisely in a depoliticized or culturalized milieu that people are able to foster solidarity within their respective groups, while instigating violence against other groups, all the while being aware of the inconsistencies between these two attitudes. However, it is important to note that despite the perceived convergences, Sen and Žižek nonetheless diverge in their fundamental positions on the role of markets. On one hand, Sen is an analytic economist and philosopher who strongly believes in the merits of the market economy in advancing individual freedoms and capabilities. On the other hand, Žižek is a Hegelian and Marxist philosopher and Lacanian psychoanalyst who remains critical of liberal capitalism.

Given Sen's identification of the roots of the mystification of culturalization to the mystifications of the idea of identity, he proceeds to classify two major mystifications of the idea of identity which link to the culturalization of violence. First is the reductionism of the notion of singular affiliation, which ascribes one and only one identity to a person. Second is the illusion of destiny, championed by popular communitarian and cultural theories, which assert that a person's identity is somewhat predetermined and merely discovered, and not chosen. ${ }^{19}$ Sen's basic position on the true character of identity is therefore characterized by two assertions against these

\footnotetext{
${ }^{16}$ Note that the terms "mystification" and "culturalization" are not directly used by Sen in his work but are part of the author's interpretation and synthesis of Sen's work.

${ }^{17}$ Amartya Sen, Identity and Violence: The Illusion of Destiny (New York: W. W. Norton \& Company, 2006), 1-3.

18 Žižek, Violence, 48-52.

${ }^{19}$ Sen, Identity and Violence, 17-20.
}

(C) 2021 Marlon Jesspher B. De Vera

https://www.kritike.org/journal/issue 29/devera december2021.pdf

ISSN 1908-7330

(c) ) BY-NC-ND 


\section{DE VERA 9}

two mystifications of the idea of identity - first, that each person has multiple and diverse identities which can coexist without contradiction, and second, that reason and choice play a central role in determining which identities each person would take, and what priority is given to each relevant identity in every particular context. It is immediately seen how these two assertions resist the mystification brought about by culturalization in the sense that it shifts the focus to the individual, which in Žižek's analysis, is paradoxically the site of the universal, as opposed to the realm of culture which is essentially collective and particular. ${ }^{20}$ Thus, it is through the rationality and choice of the individual wherein the depoliticizing force of culturalization can be resisted. In line with Sen's claim that reason and choice play a central role in resisting the mystification of identity (the mystifications of singular affiliation and the illusion of destiny), Žižek also alludes to this dynamic of active rationality and choice in identity-based thinking in a rough proposal of how the IsraelPalestine conflict could be potentially resolved-through Jews and Palestinians coming together to assert their common identity rooted on the common diasporic experiences of their peoples. ${ }^{21}$ In this case, the mystification of singular affiliation can be resisted by recognizing that Jews are not Jews alone, and that Palestinians are not Palestinians alone. Rather, people in both groups have multiple other identity affiliations, including their common identity affiliation as peoples with diasporic experiences. Moreover, the mystification of the illusion of destiny can be resisted by recognizing that both Jews and Palestinians can decide through rational deliberation on the relative importance they would ascribe to their multiple identities, and consequently acknowledge that the differences in their identities as Jews and Palestinians do not necessarily lead to violent conflict.

Sen further explicates the relationships between violence and mystified ideas of identity. In "Violence, Identity and Poverty," Sen begins his discussions by identifying two limited and narrow conceptions that attempt to account for the phenomenon of violence.22 The first is the culturalist account which posits that phenomena of violence are ultimately brought about by conflicts among cultures or collective identities. The second is the political economy view which asserts that phenomena of violence are disproportionately primarily caused by politico-economic factors such as economic oppression, inequality, and poverty. Sen argues that while each of these two positions account for a significant part of phenomena of violence, each also fails to encompass the important dynamics between the factors of culture and political economy. Consequently, each of these two positions does not provide a robustly plausible proposal on how to undermine and

\footnotetext{
${ }^{20}$ Žižek, Violence, 141.

${ }^{21}$ Ibid., 128.

${ }^{22}$ Amartya Sen, "Violence, Identity and Poverty," in Journal of Peace Research, 45 (2008).
}

(C) 2021 Marlon Jesspher B. De Vera https://www.kritike.org/journal/issue 29/devera december2021.pdf 


\section{SEN AND ŽIŽEK}

overcome violence. Sen espouses that the factors of cultural identity and politico-economic oppression must be understood together in accounting for the causes and potential solutions to violence. Sen further elaborates that the combination of the factors of poverty and mystified ideologies on the inevitability of cultural and identity-based conflicts aggravate each other and aggravate the probability of instigating violence. Consequently, formulating plausible solutions to phenomena of violence necessitates the consideration of these two factors together. Moreover, in accounting for cultural identity, the mystifications of singular affiliation and the illusion of destiny must be critically avoided in order to formulate a more plausible understanding of identity and its potential of preventing and resolving conflict.

\section{Sen's Conception of Rationality}

At this point of the discussion, it is appropriate to make further important qualifications on Sen's conception of rationality. Sen asserts that it is primarily through reason and choice that the mystifications of identity, which are the primary roots of the culturalization of violence, can be resisted. In explicating his notion of rationality, Sen characterizes it as an expanded conception and contrasts it against the narrow, Homo economicus idea of rationality. In the Homo economicus view, the deliberative process of choice of a subject or agent is deemed rational if and only if it is geared towards the advancement of the subject's or agent's personal or individual interests and goals, otherwise referred to as self-goals. If the deliberative process of choice is employed towards the advancement of other goals apart from that of selfgoals, for instance the goals of other subjects or agents, the subject or agent is deemed irrational. Sen's criticism of the Homo economicus idea of rationality is that it is too narrow and too impoverished a notion of rationality, and it fails to take into account various other reasons for choice that a subject or agent can consider in the process of deliberative choice apart from self-interests and self-goals. Sen asserts that it is possible to integrate other elements apart from self-goals into the deliberative process of choice of a subject or agent, and the resulting choice may still be considered as rational. Sen refers to a subject or agent that cannot draw the reasonable distinction between self-interests and self-goals on one hand, and rational deliberative choice on the other hand, as a "rational fool." 23

In summary, it can be said that Sen advances an expanded and pluralistic conception of rational choice to involve a process of deliberative choice that is inclusive and integrative of various other valuations, reasons, and considerations apart from self-interest or self-goal. A critical element to

${ }^{23}$ Amartya Sen, Rationality and Freedom (Cambridge: Belknap Press, 2002), 6-7.

(C) 2021 Marlon Jesspher B. De Vera

https://www.kritike.org/journal/issue 29/devera december2021.pdf

ISSN 1908-7330

(c) BY-NC-ND 


\section{DE VERA 11}

this expanded conception of rationality is Sen's idea of expanding informational bases. For Sen, in every analysis of the conduct of evaluative judgement, it is important to consider and take into account the informational bases that are included and excluded in the process of deliberation. In the context of evaluative judgements on justice, Sen criticizes both utilitarianism and libertarianism and points out that the deficiencies of both theories are rooted in their being founded on limited or narrow informational bases. Libertarianism is narrowly focused on the informational base of the absolute priority of rights while utilitarianism is narrowly focused on the informational base of utility. Consequently, each of libertarianism and utilitarianism makes evaluative judgements on justice that are exclusive of important informational bases and consequently exclusive of important valuational considerations in human affairs (i.e., consequentialist considerations in the case of libertarianism, and the normativity of human rights in the case of utilitarianism). Thus, Sen asserts an advancement towards more expansive informational bases in evaluative judgements on justice. $^{24}$

Sen's criticism of both utilitarianism and libertarianism is also consistent with two-tier, third-way, or pluralistic theories of rights, which attempt to propose more integrative and holistic conceptions of rights that take into account both the deontological moral force of rights as well as consequentialist considerations. Such attempts can be said to be consistent with Sen's capability approach which emphasizes the focus to the actual lives that people can choose to live, value, and have reasons to value. For instance, T.M. Scanlon's two-tier view is concerned with "the promotion and maintenance of an acceptable distribution of control over important factors in our lives." 25 Scanlon is similarly critical of both utilitarianism and libertarianism for the reason that both ideologies exclude certain important considerations towards the promotion of an acceptable distribution of control over valued factors in human lives. Another example is Joseph Raz's conception of "a pluralistic understanding of the foundation of morality." 26 Raz is critical of rights-based moral theories and evaluates them as too narrow in the sense that they do not provide sufficient account to the relevance of ordinary actions as well as to the moral values of supererogation, virtue, and excellence. Raz also draws the distinction between moral individualism and personal autonomy. The earlier is a primary characteristic of rights-based moral theories while the latter refers to the empowerment of human beings

\footnotetext{
${ }^{24}$ Amartya Sen, Development as Freedom (New York: Alfred A. Knopf, Inc., 1999), 55-67.

25 T. M. Scanlon, "Rights, Goals, and Fairness," in Theories of Rights, ed. by Jeremy Waldron (Oxford: Oxford University Press, 1984), 137-138.

${ }^{26}$ Joseph Raz, "Right-based Moralities," in Theories of Rights, ed. by Jeremy Waldron (Oxford: Oxford University Press, 1984), XX.
}

(C) 2021 Marlon Jesspher B. De Vera https://www.kritike.org/journal/issue 29/devera december2021.pdf ISSN 1908-7330 


\section{SEN AND ŽIŽEK}

to live lives that are consistent with their important values and ideals. Rights, among other things, could be constitutive of such an empowerment.

It can also be said that a consistent supplement to Sen's notion of rationality is John Rawls' idea of reasonability, primarily employed in his constructivist approach towards a political conception of justice. Sen's thinking was also influenced by Rawls as they were personal friends and Rawls was Sen's mentor. Rawls proposes the hypothetical original position as the starting point of the constructivist approach. The original position comprises of reasonable individuals or their representatives, under reasonable conditions, under the veil of ignorance. The veil of ignorance is a hypothetical attribute of the reasonable individuals or their representatives wherein they are ignorant about information pertaining to their self-interests or the self-interests of those whom they represent, as well as about information pertaining to the comprehensive doctrines they adopt or those whom they represent adopt. In other words, the hypothetical original position with reasonable individuals under the veil of ignorance is an ideal wherein a reasonable or a rational political conception of justice can be constructed..$^{27}$ Rawls likewise elaborately discusses his distinction between what he calls reasonability and conventional notions of rationality. It can be said that Rawls' distinction is similar to Sen's attempt to define a more expansive, pluralistic, and inclusive notion of rationality that goes beyond deliberation towards self-interest or self-goal. Moreover, in the case of Rawls, his conception of reasonability can be said to be particularly geared towards his constructivist approach towards a reasonable political conception of justice. Thus, his conception of reasonability invokes notions of fairness and impartiality, as opposed to the notion of rationality which can be situated primarily within the discursive realms of individual (and probably collective) deliberative choice. ${ }^{28}$ While there are areas of consistency between Sen and Rawls as shown in the present discussion, it is important to note that Sen's conception of rationality likewise points out the limitations in the informational bases included in Rawls' transcendental notion of reasonability. Synthesizing Sen and Rawls, my reading is that the demands of the original position and the veil of ignorance in actual practice are in a certain sense the opposite of the demands in the hypothetical sense. This is particularly in the sense that on one hand, in the hypothetical reckoning, the reasonable individuals or their representatives in the original position are demanded to be ignorant of their respective self-interests and comprehensive doctrines. On the other hand, it can be asserted that in the actual or practical setting, on the contrary, the reasonable individuals or their representatives in the actual approximation of the original position should be demanded to be

${ }^{27}$ John Rawls, A Theory of Justice, rev. ed. (Cambridge: Belknap Press, 1999), 162-168.

${ }^{28}$ John Rawls, Political Liberalism (New York: Columbia University Press, 1993), 48-54. 


\section{DE VERA 13}

fully aware of their respective self-interests and comprehensive doctrines such that they would be able to discern reasonably or rationally and be able to employ a greater extent of fairness and impartiality in their deliberation. This links back to the central role of rationality and rational deliberation in challenging the reductionisms of the notion of singular affiliation and the illusion of destiny.

Christoph Hanisch provides additional perspective on Sen's conception of rationality by providing a balanced critique of Sen's idea of rationality. ${ }^{29}$ First, he defends Sen's view from a specific criticism - that which asserts that it is not possible for a subject or agent to conduct a coherent rational process of deliberative choice based on a decisive consideration that is apart from self-interest or self-goal. The reason given in support of such criticism is that taking other goals apart from self-interest or self-goal as the decisive consideration in deliberative choice would entail the neglect of selfinterest or self-goal which are essential and integral elements of the subject's or agent's sense of self. This would result in an incoherence, and consequently irrationality in the subject's or agent's sense of self. Hanisch responds to this criticism by asserting that taking other goals apart from self-interest or selfgoal as the decisive considerations in deliberative choice does not entail a neglect of self-interest or self-goal. Instead, the different goals are taken into consideration together with self-interest or self-goal and are synchronized and integrated into a coherent and consequently rational process of deliberative choice.

Ironically, it is also from this defense that Hanisch's critique of Sen's view takes off. In his critique, Hanisch distinguishes between positive goals, which are characterized by positive and active pursuit, on one hand, and negative goals, which are not positive or active pursuits but rather negative considerations that delineate the very boundaries within which a subject or agent can make possible choices, on the other hand. Negative goals are essential and integral elements of the subject's or agent's sense of self and regulates and constrains the range of actions and decisions that a subject or agent would permit within the process of deliberative choice. Hanisch's critique is that in Sen's expanded and pluralistic notion of rationality, the accommodation of decisive considerations apart from self-interest or self-goal is nonetheless constrained by negative goals, which are implicit self-goals. Thus, in a certain sense, goals apart from self-interest and self-goals cannot be accommodated as decisive considerations. Hanisch speculates that if certain negative goals are neglected or negated by a subject or agent, this would be tantamount to the neglect or negation of essential constitutive elements of the subject's or agent's identity. My reading is that the notion of

${ }^{29}$ Christoph Hanisch, “Negative Goals and Identity: Revisiting Sen's Critique of Homo Economicus," in Rationality, Markets, and Morals, 4 (2013).

(C) 2021 Marlon Jesspher B. De Vera https://www.kritike.org/journal/issue 29/devera december2021.pdf

ISSN 1908-7330 


\section{SEN AND ŽIŽEK}

negative goals is not inconsistent with Sen's expanded and pluralistic conception of rationality. The critiques presented by Hanisch both in terms of positive goals (which he rebutted) and negative goals (which he supported) are preoccupied with the idea that neglect and negation of essential and constitutive elements of the subject's or agent's sense of self and sense of identity would lead to a process of deliberative choice that is irrational. However, in Sen's view, rationality has primacy over identity and through a rational process of deliberative choice, the subject or agent can choose to even neglect or negate essential and constitutive elements of its sense of self or sense of identity. In line with Sen's view of rationality, the subject's or agent's sense of self or sense of identity is not static but rather dynamic and subjugated to the subject's or agent's capability for rational deliberative choice.

\section{The Clash of Civilizations and Religious Violence}

It is interesting to note how both Sen and Žižek refer to the same contemporary theoretical project, namely Samuel Huntington's idea of the clash of civilizations, as a reference point of their critiques of the mystification of the culturalization of violence.

Sen's criticism of Huntington's theory of civilizational clash is founded on two main difficulties, which are ultimately rooted in his critique of the mystifications of the idea of identity. First is its impoverished notion of identity characterized by the reductionism of single affiliation, which divides the supposed civilizations of the world into discrete civilizational categories based solely on religion, and consequently ascribes the corresponding singular identities to the people of the world. Second is the simplistic assumption on the homogeneity of each civilizational classification, for which Sen cites India as an empirical example. In Huntington's theory of civilizational clash, India is classified as a Hindu civilization. However, Sen points out that India has one of the three largest Muslim populations in the world, on top of a substantial population of Sikhs, Buddhists, Christians, and Jews. ${ }^{30}$

Žižek's criticism of Huntington's theory of civilizational clash, on the other hand, is consistent with what has been discussed about Žižek's basic theoretical framework thus far. Žižek deems that the theory of the clash of civilizations is the perfect example of the formula of the culturalization of politics, by straightforwardly tracing contemporary conflicts to the conflicts among cultures. Thus, the theory of civilizational clash reinforces the depoliticizing force of post-political ideology and situates specific

${ }^{30}$ Sen, Identity and Violence, 40-42, 46-48.

(C) 2021 Marlon Jesspher B. De Vera

https://www.kritike.org/journal/issue 29/devera december2021.pdf

ISSN 1908-7330

(cc) BY-NC-ND 


\section{DE VERA 15}

contemporary problems of violence in particularist terms, for instance the Israel-Palestine conflict and the 9/11 terrorist attacks. ${ }^{31}$

Sen and Žižek also both emphasize how the mystification brought about by the culturalization of violence afflicts not only those who would like to instigate violence, but also those who intend to fight and undermine it. ${ }^{32}$ Both Sen and Žižek cite as an example the recent efforts to fight or undermine so-called Islamic fundamentalist violence through an attempt to redefine Islam as a moderate and peaceful religion..$^{33}$ Žižek opposes the separation of religion or ideology from its political expression, which is another form of culturalization or depoliticization, while Sen points out the inherent mystification of the important distinction between religious moderateness and political moderateness that results from such redefinition of religion. For Sen, a purely culturalized attempt to distinguish between religious moderateness and political moderateness in the context of violence, without taking into account important social, economic, and political dimensions, further mystifies violence and obscures possible ways to fight and undermine it. $^{34}$

To further enrich the present discussion on the depoliticization of religion, particularly of Islam, Bridget Purcell presents two attempts to reconcile Islam with the contemporary phenomenon of secularism in her review of Olivier Roy's Secularism Confronts Islam and Abdullahi Ahmed AnNa'im's Islam and the Secular State: Negotiating the Future of Shari'a. ${ }^{35}$ On one hand, Roy's book seems to advance the idea of a depoliticized Islam and argues that Islam can be considered and has actually become a purely religious phenomenon. As such, Islam can transcend any particular tradition and culture and in effect, any political system. Therefore, in Roy's reckoning, Islam can be consistent with and benign to the secular world order. On the other hand, An-Na'im's book presents an argumentative framework that is immanent from Islam or in other words from within Islam. Thus, his primary attempt is to show how the preservation of the Islamic tradition can nonetheless accommodate the secular world order. An-Na'im argues that integrating into the secular world order does not make it necessary to neglect, negate, or transcend Islamic tradition and culture. On the contrary, An-Na'im posits that certain elements of secularism, or secularism as a whole, are not only consistent with but to a certain extent even necessary for the preservation of Islamic tradition and culture.

31 Žižek, Violence, 116.

${ }^{32}$ Sen, Identity and Violence, 10-12.

${ }^{33}$ Ibid., 13-14; Žižek, Violence, 116.

${ }^{34}$ Sen, Identity and Violence, 14-15.

${ }^{35}$ Bridget Purcell, "Transcendence and Tradition: Two Attempts to Revive the Concept of the Secular," in Anthropological Quarterly, 82 (2009).

(C) 2021 Marlon Jesspher B. De Vera https://www.kritike.org/journal/issue 29/devera december2021.pdf 


\section{SEN AND ŽIŽEK}

It can be said that Roy's argument is along the lines of attempts to create a depoliticized view of Islam, or in other words attempts to distil and separate the religious content of Islam from its political connections. As such, Sen and Žižek would oppose Roy's view and identify it as a view contributing to the mystification of violence through culturalization or depoliticization. An assessment of An-Na'im's account would be less straightforward. While it is clear that an integration of Islam's religious, traditional, and cultural content with its political connections with the secular world order is attempted, this is done from a perspective that is immanent from Islam and with a clear agenda of explicating how Islam can be preserved in a secular world. Thus, the general theoretical movement is in terms of accommodating consistent elements of the secular world order into the religious, traditional, and cultural frameworks of Islam. What could have been missed out is a sufficient consideration of the tensionalities between Islam and the secular world order which are critical elements in examining the important problems regarding Islam and the politics of secularism today. An elaborate evaluation of the inconsistencies is thus as important as the attempt to demonstrate the consistencies. Nonetheless, it can be said that An-Na'im's argument is consistent with Sen's and Žižek's efforts to fully and holistically consider religion and phenomena of violence related to religion with their important and relevant political contents and expressions.

Sen takes the discussion further by presenting an analysis of the concrete repercussions of the culturalization of violence, beyond its being an intellectual barrier to a clear understanding of violence, which Sen recognizes well.

It is not hard to understand why the imposing civilizational approach appeals so much. It invokes the richness of history and the apparent depth and gravity of cultural analysis, and it seeks profundity in a way that an immediate political analysis of the "here and now" seen as ordinary and mundane-would seem to lack... As a result, the "civilizational" approach to contemporary politics (in grander or lesser versions) serves as a major intellectual barrier to focusing more fully on prevailing politics and to investigating the processes and dynamics of contemporary incitements of violence. ${ }^{36}$

${ }^{36}$ Sen, Identity and Violence, 42-43.

(C) 2021 Marlon Jesspher B. De Vera https://www.kritike.org/journal/issue 29/devera december2021.pdf ISSN 1908-7330 


\section{DE VERA 17}

After the above recognition, Sen proceeds to also assert that "cultivated theory can bolster uncomplicated bigotry." 37 Going back to the example on the recent efforts to fight so-called Islamic fundamentalism by attempting to redefine Islam, Sen asserts that paradoxically, one of the important effects of the religion-centered culturalization of politics is its inverted form, which is the politicization of religion. One concrete manifestation of this is the elevation of religious leaders as some sort of political representatives of different "communities" in the discourse of violence, which reduces the problem of violence in so-called Islamic fundamentalism to the mystified question of whether or not the true voice of Islam tolerates acts of terrorism. ${ }^{38}$ Sen also cites an example of how the politicization of religion has led to public policies that aggravate the mystifications in identity-based thinking and undermine the diversity of identities and the central role of reason and choice, such as in the establishment of more state-financed religious schools in Britain. ${ }^{39}$ Sen argues that because of these reasons, the politicization of religion undermines the role of civil society precisely at a time when it needs to be strengthened. ${ }^{40} \mathrm{In}$ a critique of Culture Matters edited by Lawrence Harrison and Samuel Huntington, Sen ultimately argues that culture does matter, particularly in the context of human development, but it should not undermine the social, political, and economic dimensions which are significant determinants and influences as well. ${ }^{41}$

\section{Conclusion}

The discussions on the mystifications involved in the culturalization of violence in this paper provide the conceptual groundwork on the fundamental theoretical frameworks employed by Sen and Žižek in their discussions on violence and present some important theses on how violence is mystified.

The theses that can be arrived at based on the presented analyses and discussions in this paper are:

1. The mystification of violence through its culturalization can be situated within a more general scheme of mystification wherein the necessary axiomatic character of politics is undermined in favor of an atonal and non-ideological pseudo-political cultural social milieu.

${ }^{37}$ Ibid., 44.

38 Ibid., 65-67, 70-79.

${ }^{39}$ Ibid., 13, 117-118.

${ }^{40}$ Ibid., 83.

${ }^{41}$ Ibid., 103-112.

(C) 2021 Marlon Jesspher B. De Vera https://www.kritike.org/journal/issue 29/devera december2021.pdf 


\section{SEN AND ŽIŽEK}

2. Central to this process of mystification is the dislocation of identitybased thinking from the universality of individual rationality and choice towards the particularism and inevitability of culture.

3. The resulting reductionisms from the mystification of violence through its culturalization afflict not only those who intend to instigate violence but also those who intend to fight or undermine it.

4. Culturalization is an intellectual barrier against the clear understanding of the political character of violence, and a culturalized conception of violence advances the narrow discourse of tolerance which is essentially mobilized by guilt and fear.

5. The culturalization of violence is not only an intellectual barrier but also has serious repercussions in how it gets manifested in its inverted form - the politicization of culture.

Philosophy Division, Department of Humanities University of the Philippines-Los Baños

\section{References}

Hanisch, Christoph, “Negative Goals and Identity: Revisiting Sen's Critique of Homo Economicus," in Rationality, Markets, and Morals, 4 (2013).

Purcell, Bridget, "Transcendence and Tradition: Two Attempts to Revive the Concept of the Secular," in Anthropological Quarterly, 82 (2009).

Rawls, John, A Theory of Justice, rev. ed. (Cambridge, Massachusetts: The Belknap Press of Harvard University Press, 1999). Political Liberalism (New York: Columbia University Press, 1993).

Raz, Joseph, "Right-based Moralities," in Theories of Rights, ed. by Jeremy Waldron (Oxford: Oxford University Press, 1984).

Sen, Amartya, Development as Freedom. New York: Alfred A. Knopf, Inc., 1999. Identity and Violence: The Illusion of Destiny (New York: W. W. Norton \& Company, 2006). , Rationality and Freedom (Cambridge, Massachusetts: The Belknap Press of Harvard University Press, 2002).

“ "Violence, Identity and Poverty," in Journal of Peace Research, 45 (2008).

Scanlon, T. M., "Rights, Goals, and Fairness," in Theories of Rights, ed. by Jeremy Waldron (Oxford: Oxford University Press, 1984).

Žižek, Slavoj, "A Leftist Plea for 'Eurocentrism'," in Critical Inquiry, 24 (Summer 1998).

"Cultural Studies versus the "Third Culture'," in The South Atlantic Quarterly, 101 (Winter 2002).

(c) 2021 Marlon Jesspher B. De Vera

https://www.kritike.org/journal/issue 29/devera december2021.pdf

ISSN 1908-7330

(c) BY-NC-ND 
M. DE VERA 19

"Eastern European Liberalism and Its Discontents" New German Critique, 57 (Autumn 1992).

, "For a Leftist Appropriation of the European Legacy," in Journal of Political Ideologies, 3 (February 1998).

Violence: Six Sideways Reflections (New York: Picador, 2008).

"History against Historicism," in European Journal of English Studies, 4 (2000).

(C) 2021 Marlon Jesspher B. De Vera

https://www.kritike.org/journal/issue 29/devera december2021.pdf 